\title{
A Transnational Gallipoli?
}

\author{
Roger Hillman
}

\begin{abstract}
Without a uniform, it is impossible to tell the nationality of a soldier's frame, and many an unidentifiable, incomplete and anonymous heap of fractured bones ended up in co-interment with those of former enemies, near monuments speciously engraved with the sentiment that 'Their Name Liveth for Evermore'
\end{abstract}

Louis de Bernières, Birds Without Wings, Chapter 71

\section{Introduction}

The Gallipoli campaign was an experience shared by a number of combatant nations. But Australia's memory of it has frequently claimed special status for Gallipoli the national legend. Completely different relationships exist now among those who fought in 1915, and representations of Gallipoli have emerged recently, in Australia ${ }^{1}$ as well as in other combatant nations, which themselves reflect tendencies not dominated by any one national state. What are the implications of this for particular disciplines? Or to rephrase that question from within one of them: 'How then should the geopolitical imaginary of the discipline of film studies be upgraded to a transnational perspective, broadly conceived as above the level of the national but below the level of the global?' (Durovičová ix). These levels of nationalism/transnationalism can work well with Gallipoli, given the limited number of participating nations, and with the subsequent memory of the campaign, which will never be global. Processing memory of the event has led to 'affinitive transnationalism ... a history of interaction giving rise to shared core values, common practices' (Hjort 17).

Australia, New Zealand, the UK, Germany, Turkey, France and India were the main nations involved, and among these nations consciousness and memorialisation of the campaign have clearly differed. Changing perceptions of Gallipoli are an instructive case study in a world of increasingly transnational perspectives. This is because the strongly national components within the originally opposed

\footnotetext{
1 Not for the first time, in relation to literary representations, but within a more globalized context. Christina Spittel reminds us that in the interwar years Australian novels appeared in which 'the hitherto mono-dimensional image of the enemy becomes more complex and diverse' (Spittel 128). Historical accounts of Gallipoli are in turn starting to have access to a broader range of (national) source materials, e.g. the ARCfunded research project directed by Harvey Broadbent, which centres on Turkish military archives and the Gallipoli campaign.
} 
alliances had different vested interests in 1915, and subsequent interests that have either converged (UK, Germany and France as EU members) or diverged further (e.g. the loosening of the British Commonwealth). The Australian legend has memorialized Gallipoli the location, and rendered Anzac Cove a virtual sacred site. This core marker of Australian identity is likely to be challenged by representations from outside. The case studies that follow help establish a narratology of Gallipoli, as the one central story is told in different artforms, representing historical narratives that are (nationally) different.

The national element of Gallipoli reception remains firm in mainstream Australian media and political culture, even eclipsing the 'NZ' in 'Anzac'. However, this article focusses on two non-Australian texts whose perspectives are very different, and outright hybrid in relation to issues of national identity. The first is the novel Birds without Wings (2004) by Louis de Bernières. The British novelist with a French name assumes a largely Turkish point of view in a work spanning a decade or so of Turkish history, with a substantial segment on the Gallipoli campaign. The second text is the documentary film Gallipoli: The Front Line Experience (2005) by Tolga Örnek. The Turkish director combines perspectives of Australian, New Zealand, British and Turkish soldiers, with a voice-over quoting their diaries and letters, alongside documentary footage and stylized re-enactments. De Bernières' novel and Örnek's film offer a memory of Gallipoli that spans former combatants. Both narrative voices convey a transnational perspective that bridges national and cultural differences by respecting them.

\section{State of the nation}

The last Australian Gallipoli veteran died in 2002, and yet Australian youths have been flocking to dawn services at Anzac Cove in recent years. So the generation with fewest direct links to the legend wishes to retain it. Beyond the first Anzacs the other combatants, on both sides, are forgotten all too easily. A few days after the 2008 Armistice Day ceremony at Anzac Cove, my Turkish guide on the peninsula, Kenan Çelik, told how the Australian representative had spoken of everyone dancing on the streets some 90 years before. 'We', he added sombrely, 'weren't'. Like 'ours', these different perspectives have been represented in historically based fiction, in literature and film. In an age of global and transnational flows, to what degree do these new angles on familiar stories interact with our self-representations? Alongside the ongoing stories of nationhood, is it possible to conceive of transnational representations of Gallipoli? What is different about those representations of Gallipoli which do not share Australia's investment in it as national myth, and what impact might a transnational approach have? 
More than six years ahead of the occasion itself, The Weekend Australian of 28-29 March 2009 featured an advertisement for a tour to celebrate the 100th anniversary of the Gallipoli landings, on 25 April 2015. Battleground tourism ${ }^{2}$ has been fostered by The Australian with group tours arranged to VillersBretonneux, billed as 'our other Anzac Day'. Though the battle on the Western front was linked to a sphere of war of far greater military importance, the primary point of reference remains Gallipoli. But there have also been challenges to its exclusivity. Paul Keating inadvertently proved the durability of the Gallipoli campaign as foundation myth ${ }^{3}$ with his vain attempt to shift focus to the Kokoda Trail. The arts world is already active in the countdown to 2015: on Anzac Day 2008, ABC radio played a movement by Peter Sculthorpe from a planned Gallipoli Symphony, to be premiered at the centenary. ${ }^{4}$ At the same time, the theme is not beyond reworking: Nigel Jamieson's play Gallipoli (2008), in the Sydney Theatre Company's production, made an explicit link between the mistakes of the imperial campaign and the Iraq War. Beyond projections, more discoveries are also likely, such as Chris Latham's retrieval of a lost violin sonata composed in the trenches of Gallipoli, and premiered at the Canberra International Music Festival this year.

The Australian Gallipoli legend has a fluctuating reception history. 'At the core of the myth' lies 'a particular construction of the Australian soldier' (Beaumont 139), a citizen soldier representing an egalitarian (and hence non-British) society, with a heightened sense of mateship (viewed, like the soldier, as distinctively Australian, rather than as a universal capacity across different national groups). John Howard even tried to incorporate a reference to mateship into a revised Australian constitution.

As the historical event Gallipoli recedes, 'cultural memory' will come to operate more fully, in the sense defined by Jan Assmann: 'in the cultural memory, the past is not preserved as such but is cast in symbols ... as they are continually illuminating a changing present. In the context of cultural memory, the distinction between myth and history vanishes. Not the past as such, as it is investigated and reconstructed by archaeologists and historians, counts for the cultural memory, but only the past as it is remembered' (113). This is the

\footnotetext{
2 In a generic sense even this, it would seem, has become 'virtually' possible. A full page advertisement in the Weekend Australian of July 28-29, 2007, encouraged a visit to the Australian War Memorial with the clarion call: 'Feel the courage of our Anzacs at the tomb of the unknown soldier'. This approaches the notion of 'prosthetic' history elaborated by Alison Landsberg (2004). Susannah Radstone (335) sounds this salutary warning in relation to the medium of film: "The assumption by theories of cinematic prosthetic memory of an equivalence between spectating a cinematic experience and living through an experience dissolves the distinction between representation and event."

3 Nor is the foundation myth aspect confined to Australia. It is also present in Mustafa Kemal's Turkey, and is further relativized by the following reminder about Turkey's ally: 'in Germany, the war constituted the first common experience for some 60 million Germans' (Julien 385).

4 This is part of a work involving ten composers and many musicians from Australia, New Zealand and Turkey. Thanks to an anonymous reader for alerting me to this.
} 
aspect of Gallipoli on which the present article focusses. However, it in no sense conceives of historians' and archaeologists' accounts of Gallipoli as secondary, nor of those accounts remaining static, as historical representations of the past in turn become contextualized in 'a changing present'.

Among reassessments, it is important to profile what is at stake here against the different project of military historian Robin Prior, signalled in the subtitle of his book Gallipoli: the End of the Myth, where his use of the word 'myth' clearly applies to popularized history $(124 ; 144)$. Prior is 'concerned to strip away the weight of mythology that has so hampered the development of a sophisticated historiography of Gallipoli' (xvi). Even after crucial adjustments to the incursions of national mythmaking on historical account, 'the weight of mythology' would continue to impinge on current perceptions of Gallipoli. Without accepting such mythology as an alternate historical version, approaching Gallipoli via influential, international literary and filmic texts largely runs parallel to Prior's project. $^{5}$

Historical memory and the more mythical inflections of cultural memory need not be mutually hostile; they are assuredly interlocked when the timeframe is that of Gallipoli. Investigating the different course of reception of the story/ legend in other nations involved in the Gallipoli campaign must enhance an understanding of Australian versions, and profile more clearly their current status. Reception of the Gallipoli legend in literature and film enables a comprehensive account of cultural memory, and a filtering of that cultural memory, not a reassessment of historical events. ${ }^{6}$ The reception of works from outside Australia can then situate the Gallipoli legend in a transnational rather than a national framework, while providing a fuller understanding of how cultural memory works in relation to the national imaginary.

\section{Peter Weir's Gallipoli}

Peter Weir's film Gallipoli (1981) and Roger McDonald's novel 1915 (1979) are key texts from the reception history of the Australian legend. Their historic moments were the after-effects of the Vietnam War and an assertive cultural nationalism; the former came on the crest of a well established New Wave of Australian films that sought to establish Australian cinema in international

\footnotetext{
5 The two converge in memory: 'Modern shared memory is located between the push and pull of two poles: history and myth'. Avishai Margalit, The Ethics of Memory, as cited in Blustein 176.

6 A distinction that can be viewed as a problematic tension by historians, here Marilyn Lake: 'As historians we think it's important to distinguish between history and mythology' (Lake 138); 'in sentimentalising history and in celebrating military virtues we fear that history as a critical practice, and as a way of explaining and understanding the past, is in danger of succumbing to nationalist mythology' (Lake 156).
} 
markets. Gallipoli was part of an almost republican discourse then, no longer relevant to its after-image now. It remains one of the most iconic depictions in Australian visual culture.

The collective mythology of mateship is easier to render in focussed form, such as the duo Archy and Frank in Gallipoli. Archy and Frank function either as an almost documentary mimesis of the core identity marker of mateship, or else as an instrument of historical persuasiveness, depending on the viewer's predisposition. Their depiction is not without dramatic cracks. The commander tells Archy that his running speed could save hundreds of lives. He is right, yet Archy's decision not to run, but to join the boys going over the top, is vindicated as moral and selfless - the question of whether he could have made it back to the commander ahead of the last whistle signal is never posed. Legend prevails over a potential flaw in dramatic characterization. This could well be Weir's take on the unanswerable paradoxes posed by Gallipoli; the film's outcome could then be read as a kind of fictional reflection of the wrong decisions and tactics associated with the campaign.

A further dramatic paradox, true to history, is the order to the boys going over the top to unload their rifles, with the bayonet charge becoming tantamount to a pointless suicide mission. Such faultlines are perhaps inevitable in 'a drama based on a myth derived from history' (Rayner 115). Outward markers of death take it out of the realm of any Australian mythology, for instance the pyramids, and the evocation of the river Styx in the film's dramatic highpoint. This is the unbridged progression from carefree waltz rhythms in Alexandria, as the troops dance with nurses, to the barely penetrable darkness surrounding the shorebound boats. The abrupt transition also returns us to what was signalled on the soundtrack over the opening credits, the funereal Adagio ascribed to Albinoni. Complemented by the duet from Bizet's Pearlfishers on the commander's gramophone, this music lends this rite of passage a transnational dimension. Both visuals and music at this turning point of the film then proclaim the irreducibility of death to the nation' (Ramazani 90), a major qualification of the way this film has been understood in Australia. The turning point marks the end of romanticized youth, its termination for those ultimately going over the top, and its farewelling by survivors like Frank. He has lived up to the emphatic claim made to his father: 'I'm not going to fight for the British Empire', but has lost those who were prepared to. From these supreme stakes it is no longer possible to disentangle Motherland from British Empire outpost, or idealistic selflessness from naïve blindness.

Weir's film has been the most influential among representations of Gallipoli which have sought to combine fiction and documentary. Where McDonald's novel 1915 based trench-scenes on interviews with returned soldiers, Weir strove for fidelity to the account of official war historian C.E.W. Bean, and 
enlisted historian Bill Gammage as adviser. He also embodied Ashmead-Bartlett's accolade of 'a nation of athletes' in the images framing the film, Archie's dawn training run at the beginning, and his breasting, in the final freezeframe, the tape of the good race he was destined to run in life. That final frame is then to be positioned in the tradition of Robert Capa, rather than European art cinema (Truffaut's 400 Blows). That Bean could have scripted at least the final sequence of Gallipoli further explains its seminal effect, given Bean's dual status as official historian of the campaign, and creator of some of its most indelible myths.

\section{Beyond Weir's Gallipoli}

Recent Australian representations of Gallipoli, especially those considered in the 'Coda' to this article, have moved beyond the static myth of the egalitarian 'mates' and their resistance to, and victimisation by, the mother country. A tone remote from Weir's is to be found in Wain Fimeri's ABC TV documentary Revealing Gallipoli (2005), whose thematic range is similar to Örnek's contemporaneous film. Alongside the Australian Peter Stanley, talking head presenters come from Turkey and Ireland, the latter alone ensuring a different shadow of the "mother country' in its own fraught relationship, especially after Easter 1916. Britishborn, Australian-based playwright Nigel Jamieson concludes Gallipoli with an Iraq link, at a time of 'the final death of a consciousness justifying the national and colonial projects of European powers' (Hamilton 139). He has also created a medium-specific Gallipoli, one of the most memorable scenes being a figure exposed to animated flies emerging from trapdoors in the stage floor, a crucial aspect of the soldier's experience that written history or fiction cannot convey so graphically.

Versions of Gallipoli emanating from campaign enemy nations are becoming available. A German military history of the Dardanelles campaign has appeared recently, likely to have been the first in 70 years. Given that Germany was Turkey's ally, this perspective alone is arresting. Klaus Wolf places very different emphases to those familiar in Australia: 'The battle of Gallipoli ... was the culmination of the struggle to resolve the 'Oriental Question'. ... Viewed from the perspective of military history, Gallipoli was moreover the first and only battle in World War I which was contested to such a degree, and on both sides, in multinational cooperation, across the armed forces. That lends it exceptional significance' (Wolf 4; my translation). Buket Uzuner's Turkish novel The Long White Cloud: Gallipoli (2002) employs magical realism to produce a counterfactual account of national heroism as enduring legend. A New Zealand soldier at Gallipoli undergoes a transmigration of souls, and national identity, 
with a slain Turkish counterpart. Inherently transnational, Uzuner's Gallipoli confounds national legend's foothold in history through celebrating its other foothold in fiction.

Recent revisionist accounts have contributed to a more genuinely rounded Australian context, one that embraces the experiences of women, of Aboriginal servicemen, of Australian soldiers from other national backgrounds. Books have started to appear which explore fascinating byways, signalled in challenging titles like John F. Williams' German Anzacs and the First World War (2003) and Eleanor Govor's Russian Anzacs in Australian History (2005). ${ }^{7}$ Brenda Walker's novel The Wing of Night (2005) in a sense tells the unadorned story that Weir's film elides early in the piece, of the women left on the West Australian land while the males are at the front. The novel goes on to explore the still more daunting societal challenge of reintegrating the returned soldier, whose homecoming to the opposite end of the world can never blot out his own moment of military glory and human abjection. The disorientation of shellshock challenges normative models of masculinity, just as this novel challenges narrower visions of Gallipoli as a crucible of national character. Never absent as authors of WWIthemed works of fiction - witness the powerful prose of New Zealander Robyn Hyde's Passport to Hell (1936) and Nor the Years Condemn (1938) - women have shed considerable light on war (see too Buket Uzuner above).

Representations of Gallipoli then occupy vantage points along two intersecting axes. One axis links historical accounts and history-related fiction, ${ }^{8}$ and the other links a more documentary realism to an engagement with mythology, within the realm of narrative forms of fiction. It is from these vantage points that war in general, and Gallipoli in particular, is viewed. When Gallipoli is told as a multiple-perspective, transnational story, this can lead various audiences in different nations to a recognition of it as a shared event rather than an exclusive one, as dominates in the Bean/Weir Gallipoli legend.

\section{Two transnational texts}

Discourses confined to an Australian perspective are challenged by the view of the Gallipoli campaign emerging from de Bernières' novel Birds without Wings,

7 Over 150 Russians fought at Gallipoli- one can only imagine the historical irony for these émigré Anzacs of trying to conquer Constantinople, which would have benefited Russia. For a little known aspect of the peninsula's history, see Shmelev.

8 This spectrum finds confirmation in an unexpected source. In his opening address at the 2008 Chief of Army's Military History conference, Lt.-Gen. Ken Gillespie introduced the year's theme, 'the issue of the media and the military' (165), and expressed his concern 'that the history of the Australian Army of the late twentieth to early twenty-first century is going to be a work of fiction - or of deduction and reconstruction. ... Only minimal holdings of written records may survive to provide the essential underpinning evidence. Without this evidence, history is, essentially, fiction' (Gillespie 168). 
and Örnek's film Gallipoli: The Front Line Experience. Their engagements with the campaign depart significantly from Weir's Gallipoli and McDonald's 1915, as both de Bernières and offer an explicitly transnational perspective on the Gallipoli campaign. Örnek does this by portraying soldiers from four combatant nations. De Bernières projects his own British background into a Turkish narrator's voice. In 1999 he wrote how his novel 'deals with the Dardanelles campaign from the Turkish point of view, a view that does not appear in the histories of the other combatants, who to this day are unaware of the role that that conflict played in the formation of the modern Turkish psyche' ${ }^{9}$

De Bernières is best known for Captain Corelli's Mandolin (1995), a novel which gives an unusual take on a lesser known theatre of war in WWII. Birds without Wings (2004) spins its tales around figures caught up in early twentieth century Turkish history. It features about a hundred pages set during the Gallipoli campaign, and above all-like Örnek, unlike Weir-bookends them with a historic contextualization of the battle. Gallipoli-the historical event, the location, and this segment of the novel - is firmly located within a web of histories, cultures, and traditions associated with the region. The novel's roving perspective includes British and Australian contributions to the campaign, without being limited to them. From Birds without Wings, though such a parallel is never explicitly drawn, we get a strong sense of the confluence of many Australian and Turkish perspectives, rather than Australian and British.

According to the Australian legend, the moral high ground allied Australia, New Zealand and Turkey against Great Britain and Germany. This novel foregrounds, further, quite different players (in particular, Greece). Gallipoli became a national rite of passage for Turkey too, as Mustafa Kemal, having gained his spurs there, oversaw the transition from the crumbled Ottoman Empire to the new nation. De Bernières gently poses the historical irony of this defining figure of Turkish nationalism having been born in Macedonia.

Inasmuch as the historical moment of de Bernières' narrative immediately postdates 9/11, the 'clash of civilizations' is viewed very differently in his novel. In fact, the narrator in Birds without Wings ultimately laments a transnational element inherent in the Ottoman Empire, and lost in the intervening history. The following excerpt refers to a population exchange between Greece and the new Turkish state, in accordance with the Treaty of Lausanne. The mutual expulsion of Muslims and Orthodox Christians, respectively, testified further to a nation-state mentality sanctioned by the victor powers of World War I. In a 'Postscript' to de Bernières' epic work, entitled 'Fethiye in the TwentyFirst Century', we read: 'In 1923 the town of Telmessos changed its name... and became Fethiye' (797). And then, as the very last sentence: 'The truly anomalous

9 'Author's Note' to the short story A Day Out for Mehmet Erbil (London: Belmont Press, 1999), 5. 
and remarkable thing about Fethiye, its market and the region of Lycia, is that there are no Greeks'. This is not a onesided stance in national disputes, though the outcome is viewed as definitely impoverishing Turkey. Rather it is a dirge for a more colourful past, when twenty-first century aspirations to transnationalism existed as a given, albeit at the cost of imperialism in a Europe defined by nationalism, and not by post-WWII aspirations to unity. ${ }^{10}$

That background is of course a major difference between Australian and Turkish focal points. According to the Australian legend, Gallipoli was a liminal space of self-definition for a recently established Federation seeking to leave behind its colonial past and redefine its relation to the mother country. The Turkish nation that ultimately emerged arose from, and in some cases excluded, former ethnic groups co-existing in an unwieldy empire. Birds without Wings indirectly pinpoints this divergence between two historical stories of nascent nationhood. Differing Australian versions of the Gallipoli legend largely remain inflections of national self-understanding. De Bernières' novel is more ambitious, and its dedication approaches at least regional history, and potentially world history from below: 'In the grand scheme of things, this book is necessarily dedicated to the unhappy memory of the millions of civilians on all sides during the times portrayed, who became victims of the numerous death marches, movements of refugees, campaigns of persecution and extermination, and exchanges of population'. That resonates with Turkey, and with Eastern Europe, but not with Australia. As does the mode of narrative voice throughout, which is one of an almost Brechtian historical irony. Forsaking the national level, a 'naïve' Turk (a figure named Karatavuk) muses on the divisions within European coreligionists, the British enemy and the German allies. The latter had a Christian 'emperor who had declared himself the protector of the Muslims. ... I thought it strange ... that these German Franks were fighting alongside us when our own Christians were forbidden to do so' (436). To rephrase the paradox: the British and Germans share their religion, and yet are national enemies, while within the work-in-progress Turkish nation, religion could exclude nationals from defending their country. Different versions of the Gallipoli legend across former antagonists begin to converge in an era more strongly marked both by secularism and by transnational influences.

After its release in Turkey, Örnek's Gallipoli: the Frontline Experience remained the number one film for five weeks. It features documentary footage, photos, interviews with international military historians, and re-enactments. The combination of 'fact' and fiction, and above all of then and now, reflects the positioning of the spectator, as colour shots of pristine beaches alternate with

10 For de Bernières' contemporary reader, this no doubt resonates with debates about Kosovo during the collapse of the former Yugoslavia. The novel's ending ironically skews contemporary transnational politics, with Greece as EU member and Turkey as EU bridesmaid. 
black and white photos of boatloads of troops landing on the same beaches in 1915. Typical of the film's narrative and style are the opening 5-6 minutes of Chapter 7 on the DVD, to which the remainder of this paragraph and the next relate. Documentary visuals, above all black and white photos and newsreeltype footage contemporary with the events, are counterpointed against reenactments in colour. The photos are of people we know to be absent, their documented thoughts (from diaries etc.) rendered as voiceover, by a voice we know is not theirs. Talking heads in colour (author Les Carlyon, military historian Christopher Pugsley, etc.) provide a further channel of information. Via the visual and acoustic link to the 'talking photos', the latter in this context seem like the animation of different witnesses or experts. The effect is another kind of re-enactment, beyond the performative aspect of voiceovers accompanying photos. In both cases talking head figures, from a range of nationalities, are blended (screen-filling portraits plus voiceover, alongside contemporary interviewees). This mix of ghostly and present voices, a technique which embodies the memory aspects of Gallipoli then and now, contrasts with palpable re-enactments of figures largely shot from behind, and hence faceless. They stand out from the photos' address of us viewers, looking straight out at us. The mismatch between photographic image and a voiceover that emanates from it but not from the person himself, combined with re-enactments that conceal faces and hence (national) identities, engages the viewer's imagination without allowing recourse to familiar stereotypes. The whole is unified by elegiac music, which does not discriminate between nationalities. As employed by Örnek, montage itself functions to suggest a transnational point of view.

In places, the film is irritatingly self-reflexive. While camera movement towards or away from photos is generally gradual, there is (at the beginning) a swishpan effect across the entourage of Ataturk, to focus on the great man himself. Extravagant fast forwards ensure that waves lapping the shores of Gallipoli are far from National Geographic-type footage. The natural beauty of the landscape is further dispelled when a 'whoosh' sound accompanies these gestures, to complete the alienation effect. The occasional 'rush' of the camera also seems to substitute for actual charges of soldiers. This in turn contrasts starkly with the slow motion rendition of soldiers' movements in the re-enactments (in one case there is also a fast forward). The slow motion sequences are a world apart from the conventional dramatic weighting of body movements elongated in time (e.g. in a film like Chariots of Fire). With Örnek their pace links photo stills and re-enactment sequences that are shot more naturalistically. A third representational medium is painting, and at the end of this sequence we see details of one by George Lambert, which refers the viewer to an Australian rather than a Turkish cultural imaginary. These details are bookended by (more 
conventional, documentary) shots of the same terrain, devoid of human life. Örnek's film is the converse of an action movie, and what emerges is a different, elegiac kind of aestheticization.

The processes and processing of memory are central to the film. Above all, the narrative kaleidoscopically combines different national viewpoints (Simpson), with profiles of a handful of participants from Australia, New Zealand, Great Britain and Turkey. Their diary entries and letters are read out on the soundtrack, conveying a ghostly oral history. But the palpable enactment that is at play, the combination of voice over and photo rather than direct recording, continually implies the limitations of oral history as a privileged perspective, too. The viewer, (re-)animating the freeze frames of history, is positioned beyond any one national perspective. The work of synthesis required of this viewer is very different to the more straightforward battlelines of national identity drawn by Weir, long unchallenged by other notable depictions in film. Jay Winter claims that the historical film genre has 'power in projecting national stereotypes and narratives' (Hughes-Warrington 80). Örnek combines cinematic devices to ensure an interaction of points of view. His montage of case studies, and the narrative voice linking them all, assembles just such a transnational perspective. Reflecting renewed international interest in the documentary genre, this film has already spawned an online study guide produced by Australian Teachers of Media, envisaging the film's use across a number of curriculum areas. This further demonstrates the importance of contrasting its approach with mainstream iconic narratives like Weir's film, something recognized at the level of the school curriculum. With Weir, the battle of the Nek succeeds the far more elaborate 'Romantic', naïve phase of adventure and war games. Örnek's film, on the other hand, gives a strong sense of the whole campaign, focussing if anything on the carnage of the first landings, especially those of the British forces. Beyond the 90th anniversary of the Dardanelles campaign, its own historic moment is Turkey's quest for EU membership, as pendant to Mustafa Kemal's mission to take his Turkey into Europe.

His film was far from uniformly popular at home, regarded by many as not nationalistic enough. ${ }^{11}$ It thus typifies what Mette Hjort (15), in her quest for 'a typology of cinematic transnationalisms', calls 'epiphanic transnationalism'. In this, 'the emphasis is on the cinematic articulation of those elements of deep national belonging that overlap with aspects of other national identities to produce something resembling deep transnational belonging' (Hjort 16). Örnek's Gallipoli diverges from the latter notion in not being part of 'the search

11 Compare debates about Clint Eastwood's Letters from Iwo Jima and Flags of our Fathers (both 2006), showing the one battle from Japanese and American perspectives. 
for effective strategies of counter-globalization' (Hjort 17). But transnational it certainly is, in its constant traversing of the perspectives of participants from a number of nations involved in the Dardanelles campaign.

\section{The wide angle lens}

With the death of the last Australian veteran in 2002, direct, first-hand memory of Gallipoli, the historical event, has gone. But remembrance of Gallipoli remains at the forefront of Australian national consciousness. The significance of Anzac Day eclipses Australia Day as the official celebration of nationhood. ${ }^{12}$ And there is no doubt that 'Anzacs' are primarily understood as Australians. On its weather page, largely devoted to world capitals, the Australian lists Gallipoli. The same newspaper nominated the 'Australian Digger' as Australian of the Year for 2006, confident that today's 'Diggers' are 'continuing the honoured tradition of the Anzacs' (McNicoll and Dodd). Behind Australian remembrance the central paradox remains of a military disaster, fought by civilian soldiers in the name of another country, being fashioned into a crucible of national formation.

However a lens anticipating the transnationalism of Örnek and de Bernières was never totally absent in Australia. Chauvel's 1940 film Forty Thousand Horsemen demonizes the Germans, while their Turkish allies in the Palestinian campaign are portrayed almost empathetically (see Gnida and Simpson). The Turks voice respect for the Australians, gained at Gallipoli, and question their German overlords, a constellation neatly paralleling Australian-British connections outside this film. The historical moment of Chauvel's film determines the way he depicts the recurrent enemy Germany, on the one hand, and Turkey, the WWI enemy, but at the time of this film, WWII neutral.

On the one hand, then, the Gallipoli legend has historical national markers within Australia. On the other, it can be aligned more closely with perceptions from outside Australia, such as that afforded by Örnek's film. Jill Matthews writes of a 'model for a transnational approach to film history' which 'derives from the dual nature of moving pictures, as both commodities and cultural products'. With regret she views this model as utopian, since 'most film historians continue to hold a strong allegiance to cultural nationalism, and hold the transnational elements in their accounts to be alien intrusions' (Matthews 168-69). Within both film history and the larger cultural frame of reference, there is no inherent

12 It stands out in a different national context: 'Gallipoli is to Australia at least what Gettysburg is to the United States' (Jackson 182). Jackson's perspectives are altogether arresting, in finding both film and legend transnational: 'It is superb in conveying the tragic futility of the Great War and thus ranks with All Quiet on the Western Front and Paths of Glory as one of the greatest anti-war movies of all time' and, referring to the Kemal Atatürk memorial on Anzac Parade, Canberra: 'Can any American imagine the United States building a monument to George III, Santa Anna, or Tojo?' (185). 
reason why a continued 'cultural nationalism', either Australian or Turkish, should prevail. Constrained by cultural nationalism, film historians would simply do violence to Örnek's film.

Why might viewing Gallipoli from a transnational perspective matter? In his speech to mark the 65th anniversary of the opening of the Australian War Memorial, Peter Stanley contested the resurgent notion of a 'Battle for Australia' in 1942, according to which the real danger of Japanese invasion had been averted, by referring to views of Japanese, US and British historians. This battle in turn has accumulated a mythological layer with the subsequent release of Baz Luhrmann's Australia (2008), which may be read as a retraction of the Gallipoli legend (home soil as battlefield; extension beyond white Australia; 'brotherhood' replacing mateship; Darwin as neglected site in the Australian imaginary).

The 'Battle for Australia' highlights the importance of not pre-empting answers to The History Question: Who Owns the Past? (Clendinnen). For 'critical novelists [and, we might add, filmmakers] share with historians the impulse-for some it is a moral imperative - to own the past, ... and to question the accretions of legend and obfuscation around past events' (Sheridan 20). Who does own the past of Gallipoli? The plurality of answers to that question need not expose history as taught in schools to the criticism of 'succumb(ing) to a postmodern culture of relativism where any objective record of achievement is questioned or repudiated' in John Howard's 2006 Australia Day Address to the National Press Club (Howard). But the plurality is queried in the name of preservation of a discipline, history as taught in Australia. From one influential vantage point, that anchoring can only be guaranteed by 'a factual narrative about the meaning of the [Gallipoli] anniversary' ('Rescuing'). 'A factual narrative' of course begs further questions. The 1915 film Heroes of the Dardanelles (dir. Alfred Rolfe), based on Ashmead-Bartlett's reports, was viewed as documentation when that was convenient, and Weir's Gallipoli obscures the fact that the order to keep going over the top at the Nek came from an Australian, not a British commander. So sensitive are these identity debates, that the first suggested subject for the 'Inaugural Prime Minister's Prize for Australian History' (2006), was 'historical events'. History lessons at school are viewed from the highest office in the land as mediating national identity (Taylor; Clark). Gallipoli is already approached in the (English and History) classroom not just as event; it is important for a transnational approach to provide materials and perspectives on what goes beyond the event.

The further historical events recede, the greater the danger of 'commemoration' answering a present need rather than any fidelity to the past (Megill 22). And that in turn can invest the phenomenon of a Gallipoli legend with new content: 'The new love of Anzac is not about Australians paying more attention to their history [...] it is about the making of historical legend as a source of national 
pride and independence, the foundation stone of a new sentimental nationalism' (McKenna 15). Transnational materials and approaches offer counter-narratives, and potentially correctives. But a sub-genre of history such as memory studies will never sit easily with a case like Gallipoli, 'because collective memory, although not entirely discounting the relevance of history to its understanding of the past, also involves a fundamentally different way of making sense of the past and of social reality, similar to the way of myth' (Blustein 200).

While Gallipoli retains its status as Australia's foundation myth, it is becoming increasingly exposed to alternate depictions in texts such as de Bernières' and Örnek's. The latter suggest new ways in which different artforms can approach the changing reception of Gallipoli over time, from transnational perspectives. They will never supplant national sentiments of celebration or mourning, but have the capacity to shift its focus, to oscillate between the national and the transnational view.

\section{Coda}

In the course of this article being written, new novels of relevance to its issues have appeared. Roger McDonald's When Colts Ran (2010), spanning much of twentieth-century Australia, has a number of passing references to Gallipoli that taper off as the WWI veteran Buckler ages and recedes from narrative view. In a sense, the novel is a male-authored pendant to Brenda Walker's approach, inasmuch as 'the mythic places where Australian men have formerly so forcefully defined their identity - the battlefield and the outback - are gone' (Hill). That sheds very different light on the ground covered by the same author's 1915, just as Gallipoli in When Colts Ran is a name alongside Troy, the Somme, or Belgium. Buckler's search for machinery in WWII loses him in the outback, emptied of any mythical aura. He embodies the history behind the myth of the battlefield: 'Buckler was the living ghost of old mates, the sworn defender who spoke for the dead. They'd spent their quota of flesh at Gallipoli and in France, and he lived the full nine lives making them right' (6). Gallipoli then figures neither as virtual experience, nor as buffeted myth, but as revenant.

The author of Traitor (2010) is Stephen Daisley, New Zealand born, now living in Western Australia. His novel has already received nominations and awards such as the Prime Minister's Literary Award for Fiction, 2011. The figure branded as 'traitor' is a simple sheep farmer, who comes under renewed suspicion for his WWI activities when New Zealand contemplates involvement in the Vietnam War. His act of 'treachery' was to enable the escape of a Turkish captive, a 
doctor, Sufi and whirling dervish, altogether a charismatic figure. Between the lines, the greater act of treachery was deemed to be regarding Mahmoud as an exceptional human being, rather than an enemy national.

Colin McLaren's Sunflower: A Tale of Love, War and Intrigue (2010) has a less extreme narrative. It tells of the author's grandfather, George Bingham, one of the longest-serving Anzacs. The prologue and acknowledgements that frame the story pay homage to 'the fireside stories of my grandad, a man who was there for 1527 nights' (295). George's 'certificate of discharge' is photocopied on p. 265 . He died in 1974, when the author was 19. The narrative in this novel is thus based on fact, while making no pretence to documentary reconstruction. Its origin locates it more in the realm of oral myth, apt for the year of the novel's release, less so for the years of the fireside chats that made such an impression, and still less for the events themselves, distanced as they are in time for both narrator and, to a greater degree, for his captive listener. Among the acknowledgements appears the name of Örnek. Comparable to Örnek's perspective, McLaren introduces a young Turkish soldier, Mehmet, as a secondary character. United by the ravages of dysentery, he and George meet under an olive branch at Gallipoli. Mehmet emigrates to Australia post-World War II, and the book concludes on the note of the peacetime reunion of two reluctant foes. The reader's introduction to Mehmet also provides background details not always present in Australian accounts, such as Churchill's withholding in August 1914 of two battleships which had been commissioned and financed by the Ottoman Empire. Above all, Sunflower departs from narratives such as that in Weir's film, in positioning Gallipoli within a far broader context. Not only do years on the Western front succeed Bingham's experiences at Gallipoli, but his return to Australia is followed by years of wandering in the countryside, avoiding family and home town, shellshocked (in this, converging with Brenda Walker's The Wing of Night). But for all its social critique the novel contrives to end harmoniously, with mutual recognition between worthy survivors of the battle of the nations.

Roger Hillman is Associate Professor of Film Studies and German Studies at the Australian National University, Canberra. Book publications include Unsettling Scores: German Film, Music, and Ideology (Indiana UP, 2005) and (co-authored) Transkulturalität: Türkisch-deutsche Konstellationen in Literatur und Film (2007). Other research interests include European cinema, and more general connections between film and music, and film and history. 


\section{Works cited}

Assmann, Jan. 'Communicative and Cultural Memory.' A Companion to Cultural Memory Studies. Ed. Astrid Erll and Ansgar Nünning. Berlin: De Gruyter, 2010. 109-18.

Beaumont, Joan. 'Gallipoli and Australian Identity.' Culture, Place and Identity. Ed. Neil Garnham and Keith Jeffery. Dublin: University College Dublin, 2005. 138-51.

Blustein, Jeffrey. The Moral Demands of Memory. Cambridge: Cambridge UP, 2008.

Clark, Anna. Teaching the Nation: Politics and Pedagogy in Australian History. Carlton: Melbourne UP, 2006.

Clendinnen, Inga. 'The History Question: Who Owns the Past?' Quarterly Essay 23 (October 2006): 1-72.

Daisley, Stephen. Traitor. Melbourne: Text, 2010.

de Bernières, Louis. Birds Without Wings. London: Vintage, 2005.

Ďurovičová, Nataša. 'Preface.' World Cinemas, Transnational Perspectives. Eds. Nataša Ďurovičová and Kathleen Newman. New York: Routledge, 2010.

Gillespie, Ken. 'Opening Address: 2008 Chief of Army's Military History Conference.' Australian Army Journal 3 (2008): 165-71.

Gnida, Antje and Catherine Simpson. 'Anzac's "Others": "Cruel Huns" and "Noble Turks".' Diasporas of Australian Cinema. Eds. Catherine Simpson et al. Bristol: Intellect, 2009. 93-102.

Hamilton, Paula. 'Sale of the Century? Memory and Historical Consciousness in Australia.' Contested Pasts: The Politics of Memory. Ed. Katharine Hodgkin and Susannah Radstone. London: Routledge, 2003. 136-52.

Hill, Lisa. 'When Colts Ran, by Roger McDonald.' ANZ LitLovers LitBlog. Posted 22 April 2011. <http://anzlitlovers.wordpress.com/2011/04/22/when-coltsran-by-roger-mcdonald/> Accessed 16 November 2010.

Hjort, Mette. 'On the Plurality of Cinematic Transnationalism.' World Cinemas, Transnational Perspectives. Eds. Nataša Durovičová and Kathleen Newman. New York: Routledge, 2010. 13- 33. 
Howard, John. 'John Howard's Australia Day Address to the National Press Club.' Australianpolitics.com. <http://australianpolitics.com/2006/01/25/ john-howard-australia-day-address.html>. Accessed 10 November 2011.

Hughes-Warrington, Marnie. History Goes to the Movies: Studying History on Film. London: Routledge, 2007.

Jackson, Kenneth T. 'Gallipoli.' Past Imperfect: History According to the Movies. Ed. Ted Mico et al. New York: Henry Holt and Co., 1996. 182-85.

Julien, Elise. 'Paris, Berlin: War Memory in Two Capital Cities (1914-1933).' Warfare and Belligerence: Perspectives in First World War Studies. Ed. Pierre Purseigle. Leiden: Brill, 2005. 379-411.

Lake, Marilyn. 'How do schoolchildren learn about the spirit of Anzac?' What's Wrong with Anzac? The Militarisation of Australian History. Ed. Marilyn Lake and Henry Reynolds. Sydney: UNSW Press, 2010.

Landsberg, Alison. Prosthetic Memory.The Transformation of American Remembrance in the Age of Mass Culture. New York: Columbia UP, 2004.

Matthews, Jill Julius. 'Modern Nomads and National Film History: The Multi-Continental Career of J. D. Williams.' Connected Worlds: History in Transnational Perspective. Ed. Ann Curthoys and Marilyn Lake. Canberra: ANU E-Press, 2006. 157-70.

McDonald, Roger. 1915. St Lucia: UQP, 1994.

—. When Colts Ran. Sydney: Random House, 2010.

McKenna, Mark. 'Patriot Act.' The Australian Literary Review, 6 June 2007: 3, $14-16$.

McLaren, Colin. Sunflower: A Tale of Love, War and Intrigue. Melbourne: Melbourne UP, 2010.

McNicoll, D.D. and Mark Dodd. 'Join Us in Saluting the Aussie Digger.' The Weekend Australian, 20-21 January 2007: 1.

Megill, Allan. Historical Knowledge, Historical Error: A Contemporary Guide to Practice. Chicago: U of Chicago P, 2007.

Örnek, Tolga. Gallipoli: The Frontline Experience. DVD. Ronin Films, 2005.

Prior, Robin. Gallipoli: The End of the Myth. Sydney: UNSW P, 2009. 
Radstone, Susannah. 'Cinema and Memory.' Memory: Histories, Theories, Debates. Ed. Susannah Radstone and Bill Schwarz. New York: Fordham UP, 2010. 325-42.

Ramazani, Jahan. A Transnational Poetics. Chicago: U of Chicago P, 2009.

Rayner, Jonathan. The Films of Peter Weir. London: Cassell, 1998.

'Rescuing a vital discipline'. Editorial. Weekend Australian, 26 August 2011. $<$ http://www.theaustralian.com.au/news/opinion/rescuing-a-vitaldiscipline/story-e6frg71x-1226123134779>. Accessed 10 November 2011.

Sheridan, Sue. 'Historical Novels Challenging the National Story.' History Australia 8.2 (2011): 7-20.

Shmelev, Anatol. 'Gallipoli to Golgotha: Remembering the Internment of the Russian White Army at Gallipoli 1920-3.' Defeat and Memory: Cultural Histories of Military Defeat in the Modern Era. Ed. Jenny Macleod. New York: Palgrave Macmillan, 2008. 195-213.

Simpson, Catherine. "Taking the "Nation" Out of Gallipoli; Tolga Örnek's Gallipoli: The Frontline'; 'Bonds of War: Interview with Tolga Örnek.' Metro Magazine 153 (June 2007): 87-95.

Spittel, Christina. 'Remembering the War: Australian Novelists in the Interwar Years.' Australian Literary Studies 23.2 (2007): 121-39.

Taylor, Tony. 'Disputed Territory: The Politics of Historical Consciousness in Australia.' Theorizing Historical Consciousness. Ed. Peter Seixas. Toronto: U of Toronto P, 2004. 217-39.

Uzuner, Buket. The Long White Cloud-Gallipoli. Trans. Pelin Thornhill Ariner. Istanbul: Everest, 2002.

Walker, Brenda. The Wing of Night. Sydney: Viking, 2005.

Wolf, Klaus. Gallipoli 1915: Das deutsch-türkische Militärbündnis im Ersten Weltkrieg. Bonn: Report, 2008. 